\title{
Pre-Service Male Teachers' Perception of E-Learning Course
}

\author{
Yu Cheng Shen ${ }^{1, \text { a* }}$ \\ 1Qujing Normal University, Yunnan Province, China \\ aroscoeshen@gmail.com \\ * Corresponding Author
}

Keywords: E-learning Course; Effectiveness; Pre-service Teachers

\begin{abstract}
E-learning has considerable flexibility in developing its accountability for instruction activities, so long as the perception is that e-learning is accessible and is successfully implemented. There has been quite a lot written about the effectiveness of online instruction, but only few studies have focused on learner perception. Results of this study show e-learning can be an effective pedagogy, especially for those e-learning courses for pre-service teachers. Factors leading to the success of the e-learning courses include pre-service teachers' perceived anonymity of online discussions, online video clip and the online format of the class.
\end{abstract}

\section{Introduction}

While returning to 1990, those terms such as blog, email, internet, yahoo.com, WWW, and many others dealing with information communication, research, entertainment, and storage mediums, even though e-learning, were not part of our vocabulary. Now they are. In fact, the Pew Internet and American Life Project estimates that about $73 \%$ of Americans use the Internet [1]. The emergence of information and communication technologies (ICT) has risen the new epoch in higher education for asynchronous and synchronous instructional activities and coursework [2]. E-learning is the unifying term that describes the fields of online learning, web-based training, and technology-delivered instruction. This study began to measure the effectiveness of e-learning format in an e-learning course.

\section{Literature Review}

E-learning is a term to depict the domains of virtual learning, web based training, and technology-delivered instruction. Bates (1999) described e-learning as the new generation of distance education. Cooper (1999) pointed out that independent learners have the potential to be successful in distance education, however those lacking in the skills to study independently may not perform well in a virtual environment. Knight (1996) reported that e-learning would benefit pre-service teachers who are more active in managing their learning. This view was endorsed by Hawkes and Cambre (2000) who claimed that in order to gain results, pre-service teachers must take responsibility for their own learning. The critical success factors in an e-learning environment are different than those in a traditional learning environment. A common theme in the findings of such studies suggests that pre-service teachers with prior experience using information technology will likely be more successful in a virtual learning environment (Volery \& Lord, 2000). Some research described curriculum design about experiential learning or instruction design in multiculturalism field like the following. Anderson and Szabo (2007) state that a course deals with multiculturalism into Teacher Education Programs could not be successful without the inclusion of experiential learning. Experiential learning includes active learning, service learning and volunteerism. Based on these research findings, it is necessary to achieve course goal with an experiential learning experience in multiculturalism courses. However, a problem occurs how those participating e-learning courses student could find time to complete volunteer hours and still meet their work and other responsibilities. Conjunction experiential learning with e-learning component in multiculturalism courses is a viable instruction to meet the requirement in multiculturalism courses. 


\section{Research Questions}

1. Is it successful in e-learning format with this class, Multicultural Diversity and Educational Leadership?

2. What are pre-service teachers' perceptions in e-learning environment?

\section{Method}

Two statistical procedures, the student $t$-test and descriptive statistics were to examine the effectiveness and identify specific characteristics that pre-service teachers reported that might be of interest to instructors. Precisely, the $t$-test based on the standard error of the difference between two means can only be used to test differences between two means; $t$-test could be used to compare pre-service teachers' scores from different learning environments., and descriptive statistics could be employed to analyze the survey data and identify important factors that relate to pre-service teachers' effectiveness in learning environments.

\section{Study Response}

The purpose of this study is to measure the effectiveness of e-learning format in a e-learning course, in terms of meeting course goals and in student satisfaction with the class. The effectiveness of this class was assessed in several ways, such as participating pre-service teachers in e-learning format completed a short answer survey to determine what they valued and did not value about the online course format, Pre-service teachers' academic performance (score), and the final exam asked pre-service teachers to apply what they had learned to themselves, their schools and their.

Table 1 Course enrollments and student characteristics

\begin{tabular}{|l|l|l|l|l|l|l|l|}
\hline \multirow{2}{*}{ Course Delivery } & \multicolumn{3}{|c|}{ Number of Students } & \multicolumn{5}{c|}{ Age of Students } \\
\cline { 2 - 9 } & Male & Female & Total & Mean & Standard Deviation & Minimum & Maximum \\
\hline Face-to Face & 19 & 16 & 35 & 37.69 & 7.502 & 28 & 55 \\
\hline IVC & 54 & 85 & 139 & 38.66 & 7.243 & 26 & 55 \\
\hline
\end{tabular}

Obviously, the participating students' age is older and all of them have experienced in full time teacher for a while (Table 1 ). Table 2 figured the outcome of $t$-test in academic achievement (Score) between IVC and face-to-face environment. It is not statistically significant in table 2 that here is no difference between IVC and face-to-face environment in academic effect. Table 3 suggests that most students rated comfort with technologies quite high and ratings of satisfaction with IVC course, the last item of the questionnaire. Table 4 summarizes the findings for Active Participation in E-leaning Activities. It showed us students' rating about active participation in e-leaning activities, and it referred to active learning in the learning process enhances learning. Table 5 addresses the issue on how students utilize the online units for self-paced study, and most ones believe that course outline helps me arrange my entire learning activities.

Table 2 The t-test for academic achievement

\begin{tabular}{|l|c|c|c|c|}
\hline Course Delivery & $\mathrm{N}$ & Score Mean & STD & $p$ \\
\hline Face-to Face & 35 & 80.1429 & 8.2583 & \multirow{2}{*}{.678} \\
\hline IVC & 56 & 82.5823 & 7.5143 & \\
\hline
\end{tabular}


Table 3 Response for comfort with technologies

\begin{tabular}{|l|c|c|c|c|c|}
\hline \multicolumn{1}{|c|}{ Question } & 1 & 2 & 3 & 4 & 5 \\
\hline $\begin{array}{l}\text { I frequently watch video clips over the } \\
\text { network. }\end{array}$ & 0 & 0 & 0.40 & 0.39 & 0.21 \\
\hline $\begin{array}{l}\text { I am familiar with downloading and } \\
\text { installing software from the network. }\end{array}$ & 0 & 0 & 0.22 & 0.57 & 0.21 \\
\hline $\begin{array}{l}\text { I feel the network operates smoothly } \\
\text { when I watch the video clips in IVC }\end{array}$ & 0 & 0.05 & 0.27 & 0.68 & 0 \\
\hline
\end{tabular}

Table 4 Response for active participation

\begin{tabular}{|l|c|c|c|c|c|}
\hline \multicolumn{1}{|c|}{ Question } & 1 & 2 & 3 & 4 & 5 \\
\hline $\begin{array}{l}\text { I can easily post my suggestions and reply to } \\
\text { messages from classmates on the bulletin board. }\end{array}$ & 0 & 0 & 0.25 & 0.48 & 0.27 \\
\hline $\begin{array}{l}\text { I always download all the reading materials } \\
\text { supplied by my teacher. }\end{array}$ & 0 & 0 & 0.64 & 0.20 & 0.16 \\
\hline $\begin{array}{l}\text { I can submit my opinions, and complete } \\
\text { homework at anytime on the bulletin board } \\
\text { without any time constraints from other class } \\
\text { members. }\end{array}$ & 0 & 0 & 0.05 & 0.72 & 0.23 \\
\hline
\end{tabular}

Table 5 Response for self-paced learning

\begin{tabular}{|l|c|c|c|c|c|}
\hline \multicolumn{1}{|c|}{ Question } & 1 & 2 & 3 & 4 & 5 \\
\hline $\begin{array}{l}\text { I feel that the course outline helps me arrange my } \\
\text { entire learning activities. }\end{array}$ & 0 & 0 & 0.20 & 0.62 & 0.18 \\
\hline $\begin{array}{l}\text { I feel that my teacher provides abundant } \\
\text { information and materials for the course. }\end{array}$ & 0 & 0 & 0.64 & 0.20 & 0.16 \\
\hline $\begin{array}{l}\text { I read and study the downloaded course materials } \\
\text { regularly. }\end{array}$ & 0 & 0 & 0.05 & 0.72 & 0.23 \\
\hline
\end{tabular}

\section{Conclusion}

The results of this case study suggest that students' achievement in this participating class is not different between e-learning format and face-to-face environment. This makes sense what the almost equal outcome was performed in e-learning environment. Learning is effective when the presentation of knowledge allows learners to both retain knowledge and easily apply it. Indeed, effective learning results in a measurable increase in learners' competency and an improvement in efficiency and quality for the society. E-learning offers a viable strategy for producing effective training, since it can provide experiential learning and a mechanism to easily track and monitor training results. Overall, students of experimental group in the course rated the e-learning as marginally positive. Issues relative to e-learning have resulted in rigorous debate in educational research (Smart \& Cappel, 2006), but include findings that e-learning has several advantages over traditional learning, such as "e-learning is considerably more convenient and flexible." E-learning also may have both pedagogical advantages over traditional methods relative to principles of learning and non-pedagogical advantages; Dommeyers et al. (Dommeyers, Baum \& Hanna, 2002) pointed out that e-learning may curtail paper costs, require less classroom time, and permit efficient processing of grades. But there are contradictions. In the survey data of this study, higher ratings on selected questionnaire items implied the instructor and peer interactions are very important. Future studies are encouraged to explore technological aspects of e-learning or to online interacting between instructor and learner in education. 


\section{References}

[1] J. van der Geer, J.A.J. Hanraads, R.A. Lupton, The art of writing a scientific article, J. Sci. Commun. 163 (2000) 51-59.

Reference to a book:

[2] W. Strunk Jr., E.B. White, The Elements of Style, third ed., Macmillan, New York, 1979.

Reference to a chapter in an edited book:

[3] G.R. Mettam, L.B. Adams, How to prepare an electronic version of your article, in: B.S. Jones, R.Z. Smith (Eds.), Introduction to the Electronic Age, E-Publishing Inc., New York, 1999, pp. 281-304.

[4] R.J. Ong, J.T. Dawley and P.G. Clem: submitted to Journal of Materials Research (2003)

[5] P.G. Clem, M. Rodriguez, J.A. Voigt and C.S. Ashley, U.S. Patent 6,231,666. (2001)

[6] Information on http://www.weld.labs.gov.cn 